\title{
1979: a Year of the Child, but Not of Children's Human Rights
}

\author{
Linde Lindkvist ${ }^{1}$ \\ University College, Stockholm \\ linde.lindkvist@ehs.se
}

\begin{abstract}
This article explores the diplomatic contestations over children's rights in connection to the International Year of the Child (IYC) of 1979. At the time, the Year was celebrated as an outstanding success, an event which helped to heighten social and political awareness of the status of children in both developing and industrialized countries, and which brought to light a plethora of new global issues, including street children, children with disabilities and children in armed conflict. Today, the IYC is frequently reduced to a plotting point in histories charting the rise of an international discourse of children's rights, a discourse that is intimately linked to the UN Convention on the Rights of the Child of 1989. This article shows how the concept of children's rights was of peripheral importance to the overarching purposes of the IYC, which instead revolved around a notion of child welfare as integral to wider projects of social and economic development, either in the form of economic sovereignty or basic needs. The article then revisits the 1978-1979 UN debates on a human rights treaty for children, showing how this project initially garnered minimal support among states, international agencies and non-state actors. The article thus takes issue with teleological accounts that see the IYC primarily as a first step toward the subsequent breakthrough of children's human rights. It also showcases how historical case studies of UN observances can be fruitful for scholars interested in the clashes and amalgamations of competing concepts and projects at an international level.
\end{abstract}

1 Senior Lecturer, School of Human Rights, University College Stockholm. The author wishes to thank Steven L.B. Jensen, the three anonymous peer-reviewers for Diplomatica, as well as the editors of this special issue - Paul van Trigt and Monika Baár - for extraordinarily constructive comments on earlier draft versions of this article. 


\section{Keywords}

International Year of the Child - children's rights - UN Convention on the Rights of the Child - UN observances - human rights history

1979 was the International Year of the Child. Even before it was over, it was hailed as an "outstanding success," an event that helped to establish children's well-being as an area of transnational action and one that breathed new life into the practice of UN observances. ${ }^{2}$ Key to this success, UNICEF historian Maggie Black argues, was that it was organized as a "do-it-yourself-affair." The year drew on vital political and financial support from within the UN system, but it was designed primarily as a platform for myriads of decentralized initiatives to promote child welfare and social development. ${ }^{3}$ Apart from the numerous national and community-level actions carried out under its aegis, the IYC helped to spotlight a set of seemingly novel issues of global concern, including child abuse, sexual exploitation, street children and the status of children with disabilities. ${ }^{4}$ Moreover, the year gave rise to influential studies documenting the shocking magnitude of more well-known problems like exploitative child labor, as well as infant and maternal mortality. ${ }^{5}$

Yet, today the IYC is not remembered for this diversity of action. When it is cited by scholars, it is principally as a milestone on the path toward the UN Convention on the Rights of the Child. Since its adoption in the fall of 1989, this treaty has been ratified by 196 states - more than any other human rights instrument - and has become the central normative frame for the multitude of actors dedicated to the cause of children's rights. In her authoritative study on the rights of children in international law, Geraldine Van Bueren argues that the IYC was a significant event because it was when "states withdrew their

2 UNICEF. Annual Report 1980 (New York: UNICEF, 1980), 13; Jolly, R. UNICEF: Global Governance that Works (London: Routledge, 2010), 59 .

3 Black, M. The Children and the Nations: The Story of UNICE F (New York: UNICE F, 1986), 360.

4 On child abuse and sexual exploitation, see Freeman, Michael D.A. Violence in the Home (London: Saxon House, 1979); Korbin, J.E., ed. Child Abuse and Neglect: Cross-Cultural Perspectives (Berkeley: University of California Press, 1983); Taylor, L., and E.H. Newberger. "Child Abuse in the International Year of the Child." New England Journal of Medicine 301 (22) (1979), 1205-1212.

5 Mendelievich, E., ed. Children at Work (Geneva: International Labour Office, 1979); World Health Organization. Maternal and Child Health (Geneva: wHo, 1979). 
opposition" to the idea of a child rights convention. ${ }^{6}$ Similarly, political scientist Anna Holzscheiter maintains that 1979 led to a "renegotiation of a global understanding of childhood as well as a notion of children's rights in international politics," and thus helped to pave the way for the convention's finalization a decade later. ${ }^{7}$

These accounts are not without merit. After all, it was during the preparations for the IYC that the Polish government tabled the first version of the convention, expecting that the drafting could be completed before the end of 1979 and thus "give a special meaning to the celebrations." ${ }^{8}$ The year also prompted renewed interest in children's rights as a concept for social and political action. The IYC, for instance, saw the emergence of a new kind of child rights organization, epitomized by the Defence for Children International, which sought to transfer the working methods of increasingly successful human rights groups like Amnesty International to the field of child protection. ${ }^{9}$ It further inspired individual thinkers like American sociologist Elise Boulding to reflect on the implicit "ageism" in international human rights documents, which generally failed to address discrimination against minors and seniors. ${ }^{10}$ Most important, 1979 prompted numerous national initiatives to strengthen the protection of children's rights, including improved legislation against child abuse in several Western democracies. ${ }^{11}$

Still, the International Year of the Child was not an unequivocal breakthrough moment for children's human rights, at least not in a context of UN human rights diplomacy. Many of the prime proponents of the year actively avoided the vocabulary of rights, instead opting for a discourse of children's

$6 \quad$ Van Bueren, G. The International Law on the Rights of the Child (The Hague: Martinus Nijhoff, 1998), 13. See also, Fortin, J. Children's Rights and the Developing Law, $3^{\text {rd }}$ ed. (New York: Cambridge University Press, 2009), 39.

Holzscheiter, A. Children's Rights in International Politics: The Transformative Power of Discourse (Basingstoke: Palgrave Macmillan, 2010), 151-152.

8 Letter from Eugeniuz Wyzner to the Director of the UN Division of Human Rights, January 18, 1978. UN Doc. E/CN.4/1284 (1978). All UN documents are located online at https:// www.un.org/documents/.

9 Defence for Children International. A History of Child Rights in Action (Geneva: DCI, 2009), 25-28. For more on the rise of human rights organizations in the 1970s, see Eckel, J., and S. Moyn, eds. The Breakthrough: Human Rights in the 197os (Philadelphia: University of Pennsylvania Press, 2012).

10 Boulding, E. Children's Rights and the Wheel of Life (New Brunswick: Transaction Books, 1979), 9 .

11 See for instance Jacobsson, U. "Legislation on Violence Towards Children: The Swedish Example." In Children and Violence (Stockholm: Akademi Litteratur, 1979), 161-166. 
basic needs, which they linked to broader agendas of social and economic development. Also, in the UN Commission on Human Rights, the idea of a new human rights convention for children appeared to be stillborn.

Relying on unpublished and published UN, UNICEF and nongovernmental records, as well as a range of secondary sources, this article takes issue with accounts that see the IYC principally as a prelude to the convention of 1989 . In contrast to mainstream accounts, it highlights how the discourse of children's rights became subordinated to other discourses and recalls the international community's strong initial reservations concerning the wisdom of a child rights treaty. More broadly, the article showcases how case-studies of UN observances can be fruitful for scholars interested in the clashes and amalgamations of competing projects at an international level. It reveals how the preparations for the child year turned the United Nations into a site where a motley crew of international bureaucrats, diplomats and NGO representatives could articulate and blend together different concepts and policies related to the aim of promoting children's well-being.

The article is divided into two parts. The first section spotlights the debates on the IYC's main objectives that took place within various UN forums in the 1970s. It locates the origins of a pro-child year among a small group of nongovernmental actors, some of which sought to clothe the project in the language of children's rights. Yet, while gaining significant support for the idea of an international year, the NGOs' appeal to rights faced opposition from influential actors within the UN family, principally UNICEF, who instead viewed the year as a chance to promote national and local efforts that would both address children's basic needs and accelerate social and economic development.

None of the year's architects seriously considered the possibility of using the year to craft a binding human rights covenant for children. Many were therefore taken aback when Poland submitted its draft convention in the spring of 1978, urging UN member states to make its adoption part of the approaching events. The article's second section centers on the initial debates that followed on the Polish proposal, mainly in the UN Commission on Human Rights. It points to the profound ideological disagreements that existed among states, international agencies and non-state actors, both on the content of children's rights, and on whether the IYC was the appropriate setting to work for their codification in human rights law.

The article concludes by suggesting that the IYC indeed can serve as an illuminating case for scholars of international child welfare and children's rights but for different reasons than are generally given. What makes the IYC an interesting historical event is not that states and international agencies suddenly realized the need for a child rights treaty. Rather, the IYC is fascinating because 
it provides a window onto competing projects of international action for child welfare shortly before the discourse of children's human rights ascended to its current hegemonic position.

On December 21, 1976, the UN General Assembly voted unanimously in favor of designating 1979 as the International Year of the Child. The stated purpose of the year was to enhance "consciousness of the special needs of children on the part of decision makers and the public," as well as to encourage states to make "programmes for children [...] an integral part of economic and social development plans." The document urged all states to "expand their efforts [...] to provide lasting improvement in the well-being of their children" and to "increase substantially the resources available for services benefiting children," including in the form of beefed-up development assistance. The concluding clauses invited international agencies, non-governmental organizations and the wider public to "participate actively" in the year and assigned the coordinating responsibility to UNICEF. ${ }^{12}$

The preambulatory clauses suggested that the year - more than a step to improve children's well-being - formed part of wider efforts to establish a New International Economic Order (NIEO). Couched in a language of "sovereign equality," and focused on steps to close income gaps between developed and developing nations, the NIEO was, as Nils Gilman puts it, "the most widely discussed transnational governance reform initiative of the 1970s."13 Though its origins and impact remain contested, the initiatives found its principal proponents among the G-77 nations and acquired political significance amidst the breakdown of the Bretton Woods system, as well as the political and economic turmoil brought about by the oil-price shocks of the early 1970s. Yet the project was not merely about securing the economic sovereignty of postcolonial states vis-à-vis multinational corporations. It also involved more or less thorough visions of an anti-colonialist and welfare-oriented world order, which, as Adom Getachew has recently shown, aspired to "realize political and economic equality at each level." ${ }^{.14}$

12 An International Year of the Child, UN Doc. A/RES/31/169 (1976).

13 Gilman, N. "The New International Economic Order: A Reintroduction." Humanity 6 (1) (2015), 1 .

14 Getachew, A. World-Making after Empire: The Rise and Fall of Self-Determination (Princeton: Princeton University Press, 2018), 154. 
In the general NIEO project of overcoming global inequity, steps like technology transfer, debt relief and regulation of foreign investments were far more pronounced than measures to improve child welfare. Still, the NIEO Declaration of 1974 spoke of "accelerating economic and social development and peace and justice for present and future generations," a phrase which made possible a connection to the field of international child welfare. ${ }^{15}$ According to Estefania Aldaba-Lim - a senior Philippine diplomat and clinical psychologist who served as UNICEF's special representative for the IYC - a central aim of the NIEO was to overcome the "economic subordination of developing countries," which has "crippled their capacity to meet the needs of their children."16 Children's well-being was thus seen as integral to a wider project of anti-colonial internationalism, and as part and parcel of social and economic development. This idea was reflected in the IYC resolution, which underscored that child welfare was significant, "not only for the well-being of the children but also as part of broader efforts to accelerate economic and social progress."17

Apart from reiterating the need for restructured north-south relations, the IYC resolution featured the concept of "basic services," a concept that was tightly linked to UNICEF and WHO. In broad strokes, this referred to projects aimed at providing para-professionals and volunteers in remote villages and impoverished urban communities with basic skills and equipment to provide underprivileged populations with, for instance, primary health care, safe water supplies and elementary education. In contrast to NIEO, which focused on structural transformation at a macro-level, basic services referred to smallscale and low-cost interventions carried out with a high degree of communal involvement. ${ }^{18}$ While seemingly at odds, these two approaches to development frequently intersected and cross-fertilized in the course of the 1970s. The most prominent example was arguably the Alma Ata conference on Primary Health in 1978, which blended NIEO principles and references to basic services with an expansive version of the human right to health. ${ }^{19}$ Similarly, the IYC

15 Declaration on the Establishment of a New International Economic Order. UN Doc. A/ RES/S-6/3201 (1974).

16 Aldaba-Lim, E. "Setting Realistic Targets for Children in the Eighties." India International Centre Quarterly 6 (1) (1979), 56.

17 An International Year of the Child. UN Doc. A/RES/31/169 (1976).

18 World Health Organization. Alternative Approaches to Meeting Basic Health Needs in Developing Countries (Geneva: WHO, 1975). For a definitive analysis of the relation between NIEO, basic needs and human rights in this period, see Moyn, S. Not Enough: Human Rights in an Unequal World (Cambridge, M.A.: Harvard University Press, 2018), 113-118.

19 World Health Organization. Primary Health Care: Report of the International Conference on Primary Health Care, Alma-Ata, UssR, 6- 12 September 1978 (Geneva: WHO, 1975). 
resolution juxtaposed programs of global equity and basic services, highlighting their shared view of child welfare as integral to a wider process of social and economic advancement. ${ }^{20}$

Far more peripheral in the IYC resolution was the language of rights. True, the preamble noted that "the year 1979 will be the twentieth anniversary of the Declaration of the Rights of the Child and could serve as an occasion to promote further its implementation." ${ }^{21}$ This declaration had emerged in the UN Commission on Human Rights in the late 1950s and had served as the organization's first comprehensive statement on the human rights of children, but by the 1970s it had received only limited circulation outside the UN. As will be detailed below, this reference was a victory for some non-governmental organizations, especially the International Union of Child Welfare, which for historical reasons attached some significance to the 1959 Declaration and the concept of children's rights. But it is worth noting that the IYC resolution's operative clauses made no further mention of rights. The resolution did not call for the elaboration of new human rights standards for children, whether in the form of an updated declaration or a binding convention.

Behind these tensions within the IYC resolution we find competing visions of what projects the year was meant to bolster. In order to discern these projects, we need to return to the mid-1970s when the idea of a pro-child year first surfaced. By all accounts, the IYC's "father and midwife" was Canon Joseph Moerman, a Catholic cleric and then Secretary General of the International Catholic Child Bureau (ICCB) in Geneva. ${ }^{22}$ Born in Courtrai, Belgium, in 1920, Moerman had come of age as a student of theology in Bruges and at the Catholic University of Leuven, specializing in the Christian ethics of Swiss theologian Emil Brunner. ${ }^{23}$ In the mid-195os he was sent to Leopoldville and, later, to Brazzaville to work for the Catholic International Education Office, where he helped to organize the first Panafrican conference on Catholic education. ${ }^{24}$ In 1967 , he was appointed as head of the ІСС B, a body which had been established in the aftermath of the Second World War to advance international

20 Hanrieder, T. International Organization in Time: Fragmentation and Reform (New York: Oxford University Press, 2015), 76-79.

21 An International Year of the Child, UN Doc. A/RES/31/169 (1976).

22 Cantwell, N., and P. Dannielle "Hommage au Chanoine Joseph Moerman." Bulletin de Défense des Enfants International 18 (1) (2012), 9.

23 Moerman, J. De Grondslagen der Christelijke Ethica bij Emil Brunner, PhD Thesis (Faculteit van Godgeleerdheid, Katholieke Universiteit te Leuven, 1949).

24 Moerman, J. "First Pan-African Catholic Education Conference." In Catholic Education in the Service of Africa: Report of the Pan-African Catholic Education Conference, Leopoldville 16-23 August 1965 (Catholic International Education Office, 1965), 13-16. 
action for children from a Catholic perspective. ${ }^{25}$ In his new role, Moerman became involved in the preparations for the World Population Year of 1974 and authored a controversial book (which for a short while was banned by the Vatican), urging Catholics to take seriously the question of overpopulation, while stopping short from challenging orthodox policies banning the use of artificial birth control. ${ }^{26}$

It was against the backdrop of these experiences that Moerman coined the idea of a year for children, acquiring support from a number of predominantly Christian non-state actors, including the YMCA, the World Council of Churches and the International Union of Child Welfare. According to Maggie Black, these groups were brought together by the perception that "the child was in danger of being drowned out by the clamour surrounding more fashionable debates." ${ }^{27}$ In Moerman's view, a year focused on the allegedly innocent figure of the child (a figure who was never defined) could serve a reconciliatory purpose, a non-negligible factor given that the recent international years on population (1974) and women (1975) had produced considerable ideological friction. ${ }^{28}$ While insisting that the IYC was free of politics, Moerman personally hoped that it would function as a forceful response to the crisis of the family unit, especially in industrialized countries. He also hoped that it might provide new impetus to the practice of international years, which to him constituted important opportunities for mankind to reflect on the "accelerated changes" of the modern age and "to acquire new attitudes and new habits." 29

In 1973, Moerman presented the idea to UN Secretary General Kurt Waldheim, who, in spite of some talk of an "international year fatigue," turned out to be favorably minded. ${ }^{30}$ The more challenging task proved to be convincing UNICEF and its Executive Director, Henry Labouisse. Following a successful public service career in Washington and at the UN, Labouisse had joined

25 "Portrait of an I.N.G.O.: The International Catholic Child Bureau," 1973, Box 1, Folder 1, Papers of Canon Joseph Moerman, KADOc Documentation and Research Center, Katholieke Universiteit te Leuven, Belgium.

26 Moerman, J. Le problème de la population: Une interpellation aux hommes de notre temps (Paris: Le Centurion, 1975). Longley, C. "Vatican orders destruction of book on birth control." The Times, February 18, 1975; Hickman, Baden. "Vatican backs down on population control book," The Guardian. February 19, 1975.

27 Black, The Children and the Nations, 354.

28 See also the introduction of Paul van Trigt in this issue.

29 Moerman, J. "1979: International Year of the Child," November 1978, Box 1, Folder 2.1, Papers of Canon Joseph Moerman.

30 Moody, Z. Les droits de l'enfant: Genèse, institutionnalisation et diffusion (1924-1989) (Neuchâtel: Éditions Alphil-Presses universitaires suisses, 2016), 213-214. 
UNICEF in 1965, just as the organization was moving beyond its initial concern with humanitarian relief to enter the field of Third World development. Throughout the 1960s and 1970s, he and the agency worked to supplant a dominant but narrow understanding of development that focused on "the construction of roads, dams, communication facilities, steel mills" and the like-with a view that revolved around the strengthening of "human resources." 31 To this end, Labouisse helped to launch the so-called "country approach," which meant providing Third World countries with material assistance, training and expertise, with the objective of allowing them to integrate the basic needs of children (e.g. health, nutrition and education) into national development plans. It was also under Labouisse's leadership that the agency established programs for providing basic services. ${ }^{32}$

One of the principles that Labouisse considered central to his and his organization's activities was the idea that "children have no politics." ${ }^{33}$ In this view, international action for children should focus on providing non-partisan relief and on stimulating local - and hence variegated - efforts to safeguard the basic conditions of subsistence. ${ }^{34}$ For this reason and out of financial considerations, Labouisse was initially against the idea of an international year. But due to mounting pressure from non-state actors and a group of state representatives on the Executive Board, including the seasoned and idealistic Aake Anker Ording of Norway, Labouisse decide to put those reservations aside. His principal conditions were that the agency acquire additional financial support from governments and that there would be no major international conference. With the 1974 World Population Conference fresh in mind, Labouisse feared that an international summit would inevitably invite ideological tension and consequently undermine UNICEF's neutrality. ${ }^{35}$

31 Labouisse, Henry. Address to UnICEF's Executive Board, May 1966. Unicef Doc. E/ ICEF/545 (1966). Reprinted in Charnow, J. and G.M. Sherwood, eds. Henry R. Labouisse: Unicef Executive Director, 1965-1979 (New York: UNICE F, 1988), 18.

32 The overarching idea was that improving the well-being of children would help to boost national development by "preparing a new generation $[\ldots]$ to cope in a creative way with the complex demands of a developing society." Labouisse, H. Address to the Third Committee of the UN General Assembly. UNICEF Doc. E/ICEF/Misc.145 (1968), reprinted in Charnow and Sherwood, 23-24. For more on UNICEF during the Labouisse years, see Jolly, UNICEF, 46-6o.

33 Grant, J.P. Address at the Memorial Service for Mr. Labouisse, April 2, 1987, Charnow and Sherwood, 79 .

34 Beigbeder, Y. New Challenges for UNICEF: Children, Women and Human Rights (Basingstoke: Palgrave Macmillan, 200o), 24-29.

35 Black, The Children and the Nations, 355. 
In various speeches and memoranda, Labouisse advanced his own take on the year's central purposes. Crucially, he envisioned the event as an opportunity, not for launching new agendas, but for enhancing political and material support for already existing projects. This included increased foreign aid to developing countries, integration of "social development" into national development plans, and greater attention to basic services. ${ }^{36}$ In this regard, Joseph Moerman agreed. The year's overarching objective was to stimulate "practical, and issue-oriented national and local programmes to directly benefit children." It would not be another year "that was all talk and no action."37

One major question that remained after UNICEF's volte-face was that of the year's timing. It was primarily in this context that the question of children's rights came to the fore. The NGOs - and above all the International Union of Child Welfare - recognized that the year 1979 would be ideal because it would coincide with the twentieth anniversary of the then little-known UN Declaration on the Rights of the Child (1959).

The 1959 declaration was of special significance to the IUCW, which functioned as the international umbrella group of the Save the Children movements. In the 1920s, these movements had drafted the first international declaration on the rights of the child, the so-called Geneva Declaration, and had successfully lobbied the League of Nations to endorse it. ${ }^{38}$ After the Second World War, IUCW tried to repeat this success, only to learn that there was limited interest in a child rights manifesto in the new United Nations organization, partly because of the ongoing discussions on a framework of universal human rights. A decade later, in the late 1950s, the UN Commission on Human Rights - then in desperate need of a success following years of little progress on a binding human rights covenant - decided to dust off and revise the IUCW draft, adopting it as the UN Declaration on the Rights of the Child. ${ }^{39}$

36 For excerpts of Labouisse's statements on the International Year of the Child, including communications to the UNICEF Executive Board, see Charnow and Moe, eds., Henry $R$. Labouisse: UNICE F Executive Director, 1965-1979, 68-73.

37 Spiegelman, J. "A talk with the 'father and midwife' of the International Year of the Child: Canon Joseph P. Moerman." UniCEF Information Bulletin no. 25, 1980, Box 1, Folder 2.3, Papers of Canon Joseph Moerman.

38 For more on the context of the 1924 declaration, see Cabanes, B. The Great War and the Origins of Humanitarianism, 1918-1924 (New York: Cambridge University Press, 2014), 289-295.

39 On the drafting of the 1959 declaration, see Marshall, D. "The Cold War, Canada and the United Nations Declaration on the Rights of the Child." In Canada and the Early Cold War, 1943-1957, G. Donaghy, ed., (Ottawa: Canadian Government Publishing, 1998), 183-214. 
The 1959 text revolved around the principle of the child's best interest, as well as the basic rights of subsistence and material welfare. ${ }^{40}$ It had garnered widespread initial support among states and was the subject of several promotional campaigns by UNESCO in the early 1960s. Yet, as Zoe Moody has recently shown, the declaration soon fell into oblivion, including among international child-welfare organizations. ${ }^{41}$ To the IUCW, the prospect of an international child year seemed like a fortuitous moment to breathe new life into the 1959 declaration, and into a wider language of children's rights, to which the Save the Children movements claimed some historical ownership. It is important to note, however, that in this setting, children's rights were principally a language for highlighting the potential contribution of non-state actors to the humanitarian and development activities of the UN special agencies like UNICEF, UNRWA and UNHCR. Within the Save the Children movement, in particular, the 1970s was a period characterized by a shift from 'charity' to 'rights,' a shift that was principally about moving from ad hoc humanitarian actions to more institutionalized co-operation with international actors. Accordingly, while the NGOS frequently referred to the concept of children's rights, they rarely made a link to the wider human rights framework, and only in the 1980s did they emerge as active advocates of a child rights treaty. 42

To some degree, Labouisse and the UNICEF also welcomed the idea of linking the IYC to the 1959 Declaration. After all, its existence meant that no other policy program was needed. But from UNICEF's standpoint, the link to children's rights was not essential, and there was no reason to insist on holding the year in 1979. In fact, Labouisse and other members of the Executive Board regarded the discourse of children's rights with some unease. While realizing that the concept could potentially be used as a synonym for children's basic needs and could serve as a means of recognizing the increased importance of NGOs, they also feared that the concept was either too legalistic or too politically charged to be fully compatible with UNICEF's priorities. ${ }^{43}$

In 1978, Kurt Waldheim weighed in on these discussions on the IYC's overall purpose, and the relationship between socio-economic development and

40 For the text of the 1959 Declaration, see UN Doc. A/RES/14/1386 (1959).

41 Moody, Z. "The United Nations Declaration of the Rights of the Child (1959): Genesis, Transformation and Dissemination of a Treaty (Re)constituting a Transnational Cause." Prospects 45 (1) (2015), 24.

42 Anér, K. Address at the opening of the an exhibition of children's drawings, Palais des Nations, Geneva, February 9, 1979. F1, c 21, Rädda Barnen International, The Rädda Barnen Papers, National Archives, Arninge, Sweden. the Guns: Children as a Zone of Peace (London: Hodder and Stoughton, 1993), 13. 
children's rights. Waldheim's statement was brief but provided a clear signal that the IYC was not about developing new norms and policies but about taking concrete steps at the national and community levels to significantly improve children's lives. "While these rights have always to be reaffirmed," he claimed in reference to the 1959 declaration, "it has to be realized that they acquire meaning only when the minimum economic and social conditions are established for their fulfilment." 44 It was in this setting that the Polish government suddenly announced that it would table a draft convention on children's rights at the 1978 session of the UN Commission on Human Rights and would work for its completion within the framework of the IYc. To the year's architects, this seemed like a step that might undermine the project's success, or as Zoe Moody aptly puts it, it appeared "comme un cheveu sur la soupe."45

\section{An Unwanted Convention}

There is still a lack of scholarship on the politics behind the Polish draft convention of 1978. Child rights scholars have generally taken the official justifications at face value, thus construing it as the fruit of "an international tradition of Polish engagement for the improvement of the situation of children all over the world." ${ }^{\prime 6}$ According to the Polish judge and politician Adam Łopatka - who chaired the working group on the convention throughout the decade-long drafting process - this tradition stemmed from "the sensitivity of Polish society to the suffering and misery of children" that emerged from the experience of two world wars, wars that had stripped from children their basic rights of subsistence, development and security, and had even made them into targets of genocidal politics. ${ }^{47}$

Writing in 2007, Łopatka also cited the legacy of two prominent Poles as key sources of inspiration. He mentioned Ludwig Rajchman - the Jewish bacteriologist and humanitarian who had helped to set up UNICEF in 1946. But above all, he pointed to the significance of Janusz Korczak - the Polish-Jewish pediatrician and pedagogue, who in the interwar period advanced, as Łopatka put it, "a contemporary concept of childhood" premised on idea "that the child is an autonomous person." This was the Korczak, who, in 1942, declined an offer of

\footnotetext{
44 Cited in Moody, Les droits de l'enfant, 222.

45 Ibid.

46 Łopatka, A. "Introduction." In Legislative History of the Convention on the Rights of the Child, vol. 1 (Geneva: Office of the High Commissioner for Human Rights, 2007), xxxvii. 
sanctuary, instead accompanying the children of his Warsaw Ghetto orphanage into the gas chambers of Treblinka. "When the Polish Government put forward the first draft convention," Łopatka claimed, "it wished to popularize Dr. Korczak's concept of childhood throughout the world."48

There may be some truth to this narrative. After all, unEsco had declared 1978 the International Korczak Year, which provided occasion for a number of events in Poland to honor his memory, albeit chiefly as a national martyr and not as a Polish-Jewish pedagogue or as a pioneering thinker of the child's right to respect. ${ }^{49}$ What is lost in this narrative are the political contexts, including the much more mundane developments in the area of UN human rights politics. As Roland Burke has recently demonstrated, the 1970s was a period in UN history when the language of human rights "was deployed with increasing vigor, but with a narrowness of purpose and an instrumentalism that threatened its future viability." It was a time when "words were abundant - and so too were competing meanings. ${ }^{50}$

One thing that many scholars have overlooked is that the Polish proposal was not new. In fact, the idea of a binding child rights treaty had already surfaced in the 1950s, during the discussions on the UN Declaration on the Rights of the Child. These debates revolved around the role of the state in child protection and child welfare. Virtually all members of the Warsaw Pact criticized the overtly humanitarian language in the original version of the text, instead calling for a document that would underscore the state's fundamental importance, including its responsibility to craft adequate legislation. Hungary insisted that the declaration's "contents will remain only desires" until it is fully clear that children's rights must ultimately be "guaranteed by the state." ${ }^{51}$ Poland went the furthest, suggesting that it would have been better to simply draft a binding convention in the first place. ${ }^{52}$

In the 1970s, these statist justifications were much more muted. Instead, the Polish UN representatives maintained that it was essential to have a child rights convention, in order to make sure that this area would not fall behind

48 Ibid.

49 Scharf, R.. "Journey to Poland 1978: Report and Reflections." Jewish Quarterly 26 (3-4) (1978) 36-40.

5o Burke, R. "The Rites of Human Rights at the United Nations." Humanity 9 (1) (2018), 128-129.

$5^{1}$ Draft Declaration of the Rights of the Child: Comments by Governments, January 12, 1959, UN Doc. E/CN.4/780 (1959), 8.

52 Ibid., 17. See also, Hoffmann, P. "UN Body Backs Child Charter," New York Times, October 20, 1959 . 
other areas of human rights law. ${ }^{53}$ Many at the time took this to refer to the newly initiated project of drafting a UN Convention Against Torture, a project which was spearheaded by Western European states like the Netherlands and Sweden. These states suspected that the Polish government was more interested in filibustering the development of human rights standards in the area of civil and political rights than in actually advancing the human rights of children. ${ }^{54}$

Notwithstanding such grievances about what Western - and particularly American - diplomats regarded as an "Eastern bloc initiative," 55 the Polish government managed to place the draft before the Commission on Human Rights in March, 1978. In this setting states generally expressed support for the idea of strengthening the international protection of children's rights. Some also supported the call to make the finalization of the convention into the IYC's denouement. "Easter [is] the time for Easter eggs," the Soviet delegate stated, suggesting that it was "during the International Year of the Child that a convention on the rights of the child should be adopted." 56

In reply, a group of non-governmental organizations-again spearheaded by the IССв and the IUCW-argued that the project was problematic. Joseph Moerman, who at this point had been named as head of the IYC committee for NGOs, spoke for many when calling for a more cautious approach: "Many studies and inquiries are being carried out within the framework of the IYC on the rights of the child and the Declaration and also several seminars and other working groups on the rights of the child have been organized on the occasion of the IYC. Some of the findings of these different activities might be interesting and worthy of being taken into account on the occasion of the final drafting of the convention. But these findings will only be known at the end of 1979. [...] Without the results of the IYC studies and inquiries to focus on as a basis, these debates could become very diffused and digress from the immediate concerns of IYC and the child."57

53 Letter from Eugeniuz Wyzner to the Director of the UN Division of Human Rights, January 18, 1978. UN Doc. E/CN.4/1284 (1978).

54 Vik, H.H., and Skage A.Ø. "Deploying the Engagement Policy: The Significance of Legal Dualism in Norway's Support for Human Rights Treaties from the late 197os." Nordic Journal of Human Rights 36 (3) (2018), 311-312.

55 Cohen, C.P. "The Role of the United States in the Drafting of the UN Convention on the Rights of the Child." Emory International Law Review 20 (2006), 187.

56 Summary record of the 1471st meeting of the United Nations Commission of Human Rights, UN Doc. E/CN.4/SR.1471 (1978), §77.

57 For this and similar remarks by observers like the International Council of Women and the International Federation of Home Economics, see UN Doc. E/CN.4/1324 (1978), annex with comments by non-governmental organizations. 
Such differences concerning the timing of the project were connected to deeper, ideological schisms over the understanding of children's rights. The Polish delegation was adamant that the Declaration of 1959 had settled the meaning of children's rights in international affairs. What was called for was not the creation of new rights, but a framework to ensure that already existing norms were recast in the shape of international law. ${ }^{58}$ In a vivid defense for an expedient process, Mawia Sheikh Fadli of Syria explained why she thought the 1959 Declaration still spoke to the present realities of children: "Nineteen years after the adoption by the General Assembly of the Declaration of the Rights of the Child, hundreds of children were still dying of hunger, disease or the consequences of natural disasters such as drought. Thousands of children were deprived of their most fundamental rights by the racist regimes of southern Africa, while thousands more in Palestine were deprived of their right to a nationality, the right to return to their own countries and to have proper housing." While noting that the promotion of children's rights ultimately boiled down to questions of "international solidarity," she claimed that the message of the 1959 declaration was still valid.59

But these sentiments were not shared by all. ${ }^{60}$ A group of Northern European states argued that the 1959 formula was both obsolete and impossible to incorporate into a binding human rights treaty. The Netherlands stated that it was "not considered sufficient to merely try and copy the Declaration of the Rights of the Child which dates back as early as 1959 and does not reflect the social, economic and cultural development and changes since then."61 Sweden also recognized the transformations of everyday life that had been brought about by social movements of the 196os and 1970s, as well as the expansions of the welfare state, stating that "in many countries, views on the family, on marriage, on the relations between children and parents and on the child as an individual having its own needs and rights have undergone important changes." 62

Only a few of the states that responded to the Polish draft in 1978 came from the UN's African and Asian bloc. While it is hard to pin down the reasons for their non-involvement, the critics of the Polish draft convention quickly

\footnotetext{
$58 \quad$ UN Doc. E/CN.4/SR.1471 (1978) §76.

59 Ibid.

6o Weisberg, D.K. "Evolution of the Concept of the Rights of the Child in the Western World." International Commission of Jurists Review 43 (1978), 49.

61 Question of a convention on the rights of the child, Report of the Secretary-General, UN Doc. E/CN.4/1324 (1978), w.

62 Ibid., dd.
} 
exploited this absence for their own ends. Some of the respondents suggested that this silence was only logical given that the Polish draft was a product of the UN as it had been in the era before decolonization. "It may also be recalled," Sweden stated, "that since 1959 a large number of States have been admitted as Members of the United Nations. These States - which did not participate in the drafting of the 1959 Declaration - ought to be given an opportunity to influence the drafting of the new convention."63

In this manner, the Polish initiative was effectively neutralized. A text that had been presented as an attempt to move the UN human rights project in a more inclusive and progressive direction was portrayed as out of touch with the current realities of children and families, and as an echo of a predecolonization era of international human rights politics.

As it turned out, the most tangible result of the Polish initiative was the General Assembly's decision to establish an open-ended working group for continued deliberations. This body would meet annually in the week before the regular sessions of the UN Commission on Human Rights and would later prove successful in crafting a text that would establish children's rights as an integral part of international human rights law and policy. The crucial point, however, is that on the eve of the International Year of the Child, it was far from evident that there ever would be a child rights convention, let alone a convention that would enjoy near universal appeal. ${ }^{64}$

One thing that has puzzled observers ever since those early talks on a UN treaty on children's rights was the silence of UNICEF. Whereas other international agencies -including the International Labor Organization, UNESCO and the WHO - supported the project, albeit with certain reservations regarding the timing and precise wording of the text, UNICEF's Executive Board did not even issue a formal response. ${ }^{65}$ Yet, when seen in the wider context of the debate on the IYC's purpose, UNICEF's non-participation appears fully logical. As noted above, the agency's leadership viewed the year as an opportunity to generate resources and publicity for the basic services programs, to provide pressure for increased international development assistance, as well as to push for deeper integration of a social aspect in national development plans.

63 Ibid., dd. For more on the transformation of the UN human rights project in the 1960s, see S.L.B. Jensen, The Making of International Human Rights: The 196os, Decolonization, and the Reconstruction of Global Values (New York: Cambridge University Press, 2017).

64 Cantwell, N. "A Convention? What Convention?" Children's Rights Bulletin, 1983, F1, fd1, RBI - NGo Committee on UnICEF, The Rädda Barnen Papers.

65 UN Doc. E/CN.4/1324 (1978), annex with general comments by specialized agencies. 
A child rights convention was, in other words, everything that the UNICEF did not want the IYC to be. It was programmatic, it was top-down, and it featured the politically contentious concept of rights. ${ }^{66}$

UNICEF's relation to children's rights became a matter of dispute at the 1979 meeting of the agency's Executive Board. While many delegates wanted the organization to remain the UN's lead-agency in matters of child welfare, they also expressed unease about the prospect of a widened mandate in the wake of the IYC's success, underscoring that "UNICEF's principal mission was to address itself to the most fundamental needs of children in developing countries." Some argued that the agency must avoid duplicating the work of "other agencies in the United Nations system" and stay clear from "rights' issues which would clash with the 'needs' mandate of UNICEF." Such concerns prompted a reply from Labouisse, who at the same meeting had flirted with children's rights, citing it as the perhaps "most universal" of all themes brought to surface by the IYC. Yet, Labouisse clarified, "the UNICEF had not entered into the realm of making public statements on the rights of children which were judgmental in character, and which would be laden with legal and other complexities." Instead, he looked for "the United Nations Division of Human Rights for the exercise of this responsibility" 67

Later, in the second half of the 1980s, UNICEF's Executive Board would re-evaluate this hands-off attitude to children's human rights. After years of non-involvement in the drafting of the convention, it became an active presence in 1985-1986, helping to boost public and political interest in the project and paving the way for the convention's massive success (at least when measured in terms of ratification and discursive impact) in the 199os and 2000s. ${ }^{68}$ In the final years of drafting, the agency also helped to make subtle changes to the convention's content, effectively linking it to UNICEF's then ongoing campaign for universal inoculation, breast-feeding and oral rehydration (the so-called "survival and development revolution"). That, however, is a different story. ${ }^{69}$

66 For more on UNICEF's relationship to rights in this period, see M. Black, Children First: The Story of UNICE F, Past and Present (New York: UNICE F, 1996), 136-139.

67 UNICEF, Executive Board Decisions 1978-1979, UNICEF Doc. E/ICEF/L.1309/Ac3d.2 (1979), 19-20, available online at https://www.unicef.org/about/execboard/index_45695. html. For Labouisse's speech, see UNICEF Doc. E/ICEF/L.1384 (1979), reprinted in Charnow and Sherwood, $73-78$.

68 Veerman, P.E. The Rights of the Child and the Changing Image of Childhood (The Hague: Martinus Nijhoff Publishers, 1992), 183 .

69 See, for instance, Nyi, N. "Building Foundations for the Castles in the Air." In Jim Grant: UNICEF Visionary, ed. R. Jolly (Florence: UNICEF Innocenti Research Centre, 2002), 82. 
This article began by highlighting the tensions - especially between nongovernmental organizations and UNICEF - on the overall objectives of the International Year of the Child. While these actors agreed to link the event to the twentieth anniversary of the 1959 UN Declaration on the Rights of the Child, they also subordinated children's rights to wider discourses of global inequity and basic needs. Even actors calling for heightened attention to the language of children's rights - such as members of the international Save the Children movement - did not yet speak of a child rights treaty. The profound differences on the purpose of the IYC and the meaning of children's rights also came to the fore during the initial debates on Poland's draft convention in 1978-1979, which, if anything, made clear that the time was not yet ripe for a binding human rights instrument for children.

If we nonetheless want to hold on to the interpretation suggesting that the IYC marked an international breakthrough in children's rights, we should at least acknowledge that what triumphed was a mainly humanitarian, protection-centered conception of the idea. As historians of childhood have noted, the first half of the 1970s saw the rise of what in the Anglophone world became known as the movement for child liberation. Propelled by the gains of the civil and women's rights movements, as well as by changing perceptions of children as legal subjects in Western jurisprudence, activist thinkers like John Holt and Shulamith Firestone maintained that the idea of universal human rights required seeing children as equals, as subjects entitled to the same rights - including economic freedom and voting rights - as everyone else. What united these thinkers and activists was a strong suspicion of the discourse of the "best interest of the child," which assumed "the wisdom of a powerful bureaucratic parent." 70

The best-interest discourse was fundamental to the 1959 UN Declaration, which the architects of the IYC held out as the authoritative statement on the rights of the child. Those favoring an understanding of children's rights recognizing children as equal human beings were therefore not wrong to think of the IYC as a backlash against liberation discourse and as a return to the age-old traditions of child saving and child protection. Writing in 1983, Malcolm D. A. Freeman noted that "the International Year of the Child does not belong to

$70 \quad$ Margolin, C. R. “Salvation versus Liberation: The Movement for Children's Rights in a Historical Context." Social Problems 25 (4) (1978), 443. 
the tradition of child liberation. Its values, its whole ethos, harked back to an earlier era of concern for children."71

During the early talks on the UN Convention on the Rights of Child, some states - especially the Netherlands and the Nordic countries - expressed similar concerns about the conservative and paternalistic ethos of the 1959 declaration. Yet, even if the drafting process that followed in the 1980 s would lead to the inclusion of some civil and political rights for children, those rights including freedom of expression and freedom of religion - were generally couched in watered-down terms, at least when read alongside parallel clauses in the Universal Declaration of Human Rights of 1948 or the general UN human rights covenants of 1966. It is certainly true that the International Year of the Child helped to stimulate what later would evolve into an intense engagement with children's rights in international politics. However, the frame for this discussion was not the discourse of universal human rights as some child liberationists had hoped, but rather the 1959 declaration's understanding of children as a distinct, and inherently vulnerable, social class, a class which remains in constant need, not of freedom, but of protection and guidance.

These conceptual disagreements of the 1970s merit further research, especially studies foregrounding the relationship between the uses of children's rights at the international and domestic levels. As suggested here, there are also strong reasons for historians of human rights and scholars of child welfare and children's rights to return to the multitude of activities and projects that were launched as part of the International Year of the Child. The principal point, however, is that we should study 1979 not because the year served as a pivoting moment for our current discourse of children's human rights. Rather, the IYC commands our attention because it was a time when children's rights clashed and fused with competing visions of transnational action for children, including visions centered on global economic transformation, as well bottom-up projects of communal development, visions which have since lost their appeal.

71 Freeman, M.D.A. "The Rights of Children in the International Year of the Child." Current Legal Problems 30 (1) (1980), 24. See also Franklin, A., and B. Franklin. "Growing Pains: The Developing Children's Rights Movement in the UK." In Thatcher's Children?: Politics, Childhood and Society in the 1980s and 199os, eds. Pilcher, J. and S. Wagg (London: Falmer Press, 1996), 96-97. 